Удк: 631. 11: 330.342

JEL Classification: 01

\author{
д. І. КОЛОМИЙчУК, \\ acniparm, \\ Харківський національний \\ університет імені В. Н. Каразіна
}

\title{
Концептуальні підходи до дослідження розвитку господарських систем в умовах глобалізації та регіоналізації
}

В статті обтрунтовано взасмодію начіонального та глобального в економічних перетвореннях у відкритих господарських системах. Визначено кончептуальні підходи до розвитку господарських систем в умовах глобалізауії та регіоналізачіі.

Ключові слова: економіка, глобалізачія, інтерначіоналізауія, регіоналізауія, peziоналізм.

Постанова проблем в загальному вигляді та її зв'язок із важливими науковими або практичними завданнями. Сутнісною ознакою сучасності $\epsilon$ стрімка глобалізація економіки, що супроводжується посиленням структурної взаємозалежності національних господарських комплексів, підвищенням ступеня їх відкритості, зростанням транскордонних потоків товарів, послуг, капіталів, інтенсивним обміном інформацією, технологіями тощо. Висока динамічність торговельних, фінансових, інформаційно-технологічних потоків та багатогранність форм прояву економічної активності утворюють надзвичайно складну ієрархію зв'язків і залежностей, загострюючи наявні та породжуючи нові суперечності.

Загальновизнано, що сучасний світогосподарський розвиток має ознаки трансформаційного процесу. На думку відомого західного дослідника I. Валлерстайна, соціум першої половини XXI ст. за своєю складністю, нестабільністю й водночас відкритістю набагато перевершить усе, бачене нами в XX ст. Нинішній стан світосистеми вчений характеризує як “відхилення від стану рівновагиьТа досягненням точки біфуркації" $[1$, с. 96].

За сучасних умов глобальна мегасистема економічних координат, ї̈ кількісні та якісні параметри, вектор господарської еволюції, коридор економічної свободи 3 об'єктивними обмеженнями створюють той необхідний контекст, у межах якого формуються відмінні риси та властивості основних ешелонів сучасного світогосподарського розвитку: центру, або ядра, перехідних (транзитивних) економік, традиційних, або периферійних, економічних систем. Йдеться про те, що трансформації, які відбуваються на рівні національної економіки, накладаються на глобальні перетворення світогосподарської системи, породжуючи складну мозаїку взаємовпливу та взаємопереплетення різнорівневих системних переходів. Відтак науковці все більше переконуються в тому, що марно аналізувати процеси суспільного розвитку наших різноманітних національних "суспільств" так, нібито вони були автономними внутрішніми структурами, що розвиваються, в той час як вони $є$ і завжди були, насамперед, структурами, створеними світовими процесами і такими, що набувають своєї форми як реакція на ці процеси.

Таким чином, глобалізація належить до тих небагатьох наукових проблем, які дають змогу системно осмислити та зрозуміти трансформаційні явища XXI ст. Загальновизнано, що поглиблення глобалізації є важливим каталізатором постсоціалістичних трансформацій. Водночас формування єдиної планетарної соціально-економічної системи неможливе без залучення до цього процесу країн колишнього соціалістичного табору. Відтак дослідження сутності, суперечностей та альтернатив флобалізації поглиблює розуміння джерел, рушійних сил та сучасного стану постсоціалістичних перетворень, ініційованих як внутрішніми проблемами розвитку командно-адміністративних економік, так і зовнішніми суперечностями руху капіталістичної світ-системи по традиційній траєкторії. 3 позиції сучасної глобальної еволюції трансформаційні процеси в більшості постсоціалістичних країн поєднують унікальність та концепту-

Д. І. Коломийчук, 2017 
альну традиційність. Реалізуючись за сценарієм впливових міжнародних фінансовоекономічних організацій, такі трансформації фактично є революційними лише для країн, у яких вони відбуваються, водночас у широкому розумінні вони є більш ніж еволюційними, оскільки працюють за задумом не на знищення, а на зміцнення панівної у світі традиційної економічної системи.

Вищезазначене обумовлює актуальність досліджень концептуальних підходів до розвитку господарських систем в умовах глобалізації та регіоналізації.

Аналіз останніх досліджень і публікацій. Важливою компонентою дослідження рівня та якості глобалізаційних та регіональних процесів у інтеграційній взаємодії, iï впливу на структурні зміни, що відбуваються в національних економіках країнінтегрантів, стає комплексний аналіз інтеграційних процесів, що відбуваються на різних рівнях. На це у своїх дослідженнях звертають увагу як міжнародні інституції (OOH, Конференція ОOH з торгівлі та розвитку (UNCTAD), COT, Світовий банк та регіональні банки розвитку, OECP, EUROSTAT), так і окремі дослідники (О. Булатова, С. Винокуров, К. Григорян, І. Гурова, Т. Кальченко, Ф. де Ломбарджі та ін.). Систематизація існуючих методичних підходів до формування системи оцінювання регіональної економічної інтеграції дозволить підвищити якість оцінювання глибини та масштабів глобальної та регіональної інтеграції із використанням різноманітних показників кількісного, так і якісного характеру.

Метою статті $\epsilon$ аналіз концептуальних підходів до дослідження розвитку господарських систем в умовах глобалізації та регіоналізації.

Виклад основного матеріалу 3 повним обгрунтуванням отриманих наукових результатів. Прихильники економічної синергетики трактують глобалізацію як закономірний наслідок чергування ієрархізації та деієрархізації соціальних дисипативних структур, переплетення множинності локальних трансформацій, які породжують планетарну самоорганізацію, що охоплює всі аспекти соціального життя та всі регіони земної кулі. Вважається, що глобальна самоорганізація може бути абсолютною та відносною. На відміну від відносної (тимчасової, минущої) глобалізації, яка завершується дезінтеграцією та деієрархізацією глобальних структур, абсолютна глобалізація є необоротною, основаною на потенційно нескінченній послідовності відносних глобалізацій.

На нашу думку, глобалізація є закономірним наслідком взаємовпливу та взаємопереплетення множинності локальних трансформацій різнорівневих соціальноекономічних систем, планетарна самоорганізація яких породжує нову якість світогосподарського розвитку. Ця нова якість пов'язана з переходом від взаємодії національних економік та політичних систем на світовому полі до взаємодії глобальних гравців на полях національних держав тією мірою, якою глобальні геоекономічні та геополітичні процеси є домінуючими стосовно національних [2, с. 170]. Як зазначає Е. Кочетов, сучасна світова економіка - це складна мозаїка із держав та наддержавних транснаціональних утворень - інтернаціоналізованих відтворювальних ядер (циклів). За цих обставин національні економіки перетворюються на інтернаціональні, а на світовій арені взаємодіють не країни; а країни-системи. Йдеться про невідповідність економічних кордонів країн-систем кордонам національних держав внаслідок “проникнення" інтернаціональних відтворювальних ядер крізь національні економіки та "виривання" 3 них окремих анклавів для участі в глобальних циклах [3, с. 37].

Таким чином, глобальний світ є цілісністю, яка формується не стільки елементами, скільки взаємозв'язками. Не вдаючись до дискусії щодо інтерпретації сутності глобалізації, необхідно виокремити кілька принципових моментів, важливих для подальших міркувань. Йдеться про те, що глобалізація:

- пов'язана 3 переходом від індустріальної до постіндустріальною стадії економічного розвитку;

- означає якісно новий етап поглиблення взаємозв'язків у економічній, політичній, культурній сферах на основі підвищення мобільності капіталу, робочої сили, інформації, ідей у світовому масштабі;

- втілюється в зростанні взаємозалежності країн світу в результаті інтенсифікації міжнародних переміщень товарів, послуг, капіталів, швидкої й широкої дифузії технологій тощо; 
- потребує спільних зусиль урядів держав і міжнародних організацій щодо регулювання на планетарному рівні.

У цьому контексті заслуговує на увагу підхід відомого західного дослідника М. Кастельса, який вважає, що на сьогодні у світі формується економіка нового типу, яка одночасно $є$ інформаціональною (оскільки продуктивність та конкурентоспроможність їі агентів залежить насамперед від їх здатності генерувати, обробляти та ефективно використовувати інформацію, основану на знаннях) та глобальною (оскільки такі види економічної діяльності, як виробництво, споживання та циркуляція товарів та послуг, а також їх складових, організуються в планетарному масштабі - безпосередньо або з використанням розгалуженої мережі, яка пов'язує економічних агентів). Така економіка $є$ одночасно інформаціональною та глобальною, оскільки в новітніх економічних умовах досягнення певного рівня виробництва, якості та конкурентоспроможності можливе лише через включення в глобальну мережу взаємозв'язків, що склалися в останній чверті XX ст. як наслідок розвитку сфери інформаційних технологій $[4$, с. 150$]$.

Отже, очевидно, що інформаціоналізація та глобалізація̆ $є$ взаємопов'язаними аспектами єдиного процесу, що відбувається в сучасному світі. Нині людство перетворюється на функціонально єдину економічно-інформаціональну систему, яка в цілому утворюе ноосферну оболонку планети. Ідеться про першочерговість електронно-інформаційних основ світогосподарської діяльності, серцевиною яких $е$ продукування нового знання. Іншими словами, на рівні сучасної інформаціональноглобальної економіки людство виступас як реальна світ-системна сдність, основою узгодженого функціонування якої є глобальна електронно-інформаційна мережа світових комунікацій.

Трактуючи глобалізацію як всеохопний, багатовимірний, нерівномірний, складний та суперечливий процес, який відіграє системотворчу роль у формуванні загальнопланетарної цілісності людства, важливо зауважити, що "саме глобалізація економіки формує основу всіх глобалізаційних процесів, є мотором та задає імпульс їх розвитку. Інші сфери суспільного життя більш інерційні, ніж економіка, і за своїми темпами та глибиною глобалізація в цих галузях суттєво поступається глобалізації економіки" [5, c. 206]. Таким чином, глобалізація економіки - домінуюча складова глобалізації, емерджентна ознака закономірного процесу, об'єднання найважливіших секторів національних економік у взаємопов'язану систему, яка у своїй цілісності функціонує в режимі реального часу [6, с. 320]. Йдеться про становлення нової системної цілісності, здатної розвиватися на власній основі. Оскільки саморозвитою глобальної економіки породжує синергетичний ефект, окремі компоненти цієї системи не можуть бути довільно виокремлені $з$ неї без втрати їх нової природи.

Важливо зазначити, що глобалізація економіки є процесом динамічної взаємодії двох протилежно спрямованих тенденцій:

- інтеграції - становлення суперечливої цілісності нового планетарного соціально-економічного устрою, його уніфікації;

- дезінтеграції - збереження відособленості національно-державних та цивілізаційно-культурних утворень, їх диференціації.

Така суперечливість глобалізації виявляється в інтенсифікації взаємопроникнення національних економік, злитті та укрупненні економічних систем і міжнародних ринків, формуванні глобальних економічних союзів, створенні наднаціональних органів управління, з одного боку, та в зростанні фрагментарності світового економічного простору, урізноманітненні траєкторій національного господарського розвитку, локалізації економічної активності, посиленні культурної диференціації народів та поглибленні асиметрії розвитку, з іншого. Ідеться також про тенденції послаблення взаємозв'язків між елементами гіпервеликої глобальної економічної системи в результаті локалізації економічних відносин у формі макрорегіональних угруповань, "економічного націоналізму" окремих країн, маргіналізації, витіснення найбідніших країн на узбіччя цивілізаційного прогресу та своєрідного “замикання" постіндустріальних економік.

Як відомо, інтеграція світової економіки є наслідком тривалого процесу інтернаціоналізації, який передбачає "дисперсію економічної діяльності суб'єктів 
підприємництва через національні кордони", "вихід чогось суто внутрішнього за первинні межі або об'єднання дій декількох суб'єктів світової економіки і політики довкола загальних для них завдань, цілей, видів діяльності" [7, с. 184].

Водночас питання співвідношення між глобалізацією економіки та її інтернаціоналізацією залишається дискусійним. Аналіз економічної літератури дає змогу виокремити такі підходи:

- ототожнення глобалізації з інтернаціоналізацією виробництва й капіталу, підкріпленою зрілими інституційними відносинами й відповідними інформаційними технологіями;

- трактування глобалізації як сучасної (новітньої) стадії інтернаціоналізації господарського життя, у межах якої світове господарство набуває якісно нових характеристик, пов'язаних із формуванням його органічної цілісності; різким посиленням взаємозалежності економік практично всіх країн світу; залученням раніше закритих економік у міжнародні відносини; економічною гомогенізацією світу (посиленням однорідності, подібності форм та методів господарювання);

- аналіз інтернаціоналізації як історично-еволюційної підготовки глобалізації, так званої протоглобалізації. Прихильники зазначеної позиції виходять із того, що саме інтернаціоналізація, яка вже відбулася і на сьогодні охоплює весь світ, забезпечила світовий характер господарських та торговельних зв'язків, появу адекватної системи транспортних та комунікаційних засобів, всезагальну лібералізацію ринкових зв'язків тощо. Водночас глобалізація ще не стала таким всеохопним процесом. ІЇ̈ розгортання пов'язано з локальними модернізаційними процесами, подоланням спротиву антиглобалістських сил та спадку інтернаціоналізації, що отримав назву "асиметричної взаємозалежності".

Варто погодитися 3 тим, що в умовах глобалізації інтернаціоналізація економіки набуває нових рис, пов'язаних із планетарною діяльністю транснаціональних корпорацій; розвитком довгострокових виробничих зв'язків, стратегічних альянсів, договорів про співдружність; кардинальною зміною змісту світових господарських процесів, спрямованості та структури міжнародної торгівлі; якісними перетвореннями фінансової сфери; зростанням ролі та значення глобального капіталу, інтенсифікацією його територіальної експансії та функціональної диверсифікації; посиленням орієнтації розвинених економік на розгортання всіх сфер людської активності; інтенсифікацією пошуку світового центру управління та інструментів регулювання глобальних світогосподарських процесів.

Аналіз провідних тенденцій розвитку сучасної світогосподарської системи засвідчує, що своєрідною реакцією на виклики глобалізації й водночас однією з їі рушійних сил, починаючи із середини XX ст., $є$ регіональна інтеграція - процес формування міждержавних утворень різного типу, насамперед регіональних торговельних угод щодо преференційної й вільної торгівлі та митних союзів.

Таким чином, у сучасному світі склалася ситуація, за якої переважна більшість країн одночасно втягнута в глобальні та регіональних утворення. Відтак важливого значення набуває проблема співвідношення регіоналізації та глобалізації як комплементарних чи альтернативних процесів [8, с. 110].

Аналіз засвідчує, що в сучасній науковій літературі поняття регіоналізації трактується суперечливо, а саме:

- як відповідь на виклики глобалізації, яка доводить, що глобальні процеси не $є$ неминучими. Так, Г. Семенов та М. Панков вважають, що "тенденцію регіоналізації можна, очевидно, розглядати як своєрідну спробу країн - учасниць регіонального об'сднання протистояти всім негативним наслідкам, які має глобалізація, що асоціюється, насамперед, з гегемонією США та їхніх ТНК”. Визнані лідери світової економічної науки П. Кругман та Д. Бхагваті дотримуються думки, що регіоналізація стримує лібералізацію в глобальному масштабі та перешкоджає зниженню середньосвітового рівня протекціонізму;

- як природний процес розвитку, проміжний етап або еволюційна ланка на шляху становлення глобальної економічної системи. На думку Ю. Пахомова 
та Ю. Павленка, економічний регіоналізм $€$ характерною особливістю глобальної економіки, системотворчим центром якої є визнат̆ене I. Валлерстайном світ-системне ядро [9, с. 421].

Слід погодитися 3 тим, що регіоналізація сприяє лібералізації зовнішньоекономічних зв'язків у межах усього світового співтовариства. Окремі країни включаються в глобальний економічний поділ праці саме через інтенсифікацію своїх зв'язків з одним із трьох домінуючих регіонів: Північною Америкою, об'єднаною Європою або Азійсько-Тихоокеанським регіоном. Таким чином, можна говорити про своєрідний поділ праці між глобальними та регіональними системами, покликаними в ідеалі діяти в ім'я досягнення однієї мети. Регіони та мережі стають взаємопов'язаними полюсами в межах нової просторової мозаїки глобальних інновацій. Все це досить наочно засвідчує певну комплементарність в розвитку цих процесів.

Водночас регіоналізація та глобалізація можуть вступати в глибокі суперечності за умов, коли регіональна інтеграція сприяе інтенсифікації економічних зв'язків усередині угруповань, які перетворюються на все більш ізольовані та самодостатні утворення. Прикладом такої суперечливості є ситуація щодо регулювання міжнародної торгівлі в межах Світової організації торгівлі (СОT). Загальновідомо, що угоди СОТ грунтуються на принципі недискримінаційності, закріпленому в режимі найбільшого сприяння, який зобов'язані надавати один одному члени цієї організації. Однак створення навіть найпростішого регіонального інтеграційного угруповання у вигляді зони вільної торгівлі передбачає запровадження преференційного режиму для їі учасників і фактично заперечує режим найбільшого сприяння. У цьому контексті можна стверджувати, що регіоналізація світового економічного процесу не усуває бар'єри на шляху глобальної інтеграції, а лише змінюе їхпросторову конфігурацію. Важливо також враховувати, що у процесі “одномірної” уніфікуючої глобалізації, яка сприймається як еквівалент американізації світового простору, регіональна інтеграція $€$ однією 3 форм підтримки та захисту суверенітету національної держави.

Таким чином, регіоналізація є одночасно стимулюючим та стримувальним чинником процесу глобалізації, який дає змогу вирішити суперечності між інтеграційними та дезінтеграційними тенденціями у світовій економічній системі. Йдеться про антиномічність процесу глобалізації, яка формує об'єктивну необоротність виникнення регіональних утворень як способу зниження ентропійності світового ринку та приведення рівня хаотичності світового господарства до економічно прийнятного. Відтак на сучасному етапі світова економіка постає як матриця, утворена регіональними просторами, які взаємодіють у межах певних функціональних площин -потоків (торгових, фінансових, виробничих, інформаційних).

У цьому контексті заслуговує на увагу розмежування в сучасній економічній літературі двох “хвиль” регіональної інтеграції, що отримали назву старого та нового економічного регіоналізму.

Старий економічний регіоналізм існував в умовах біполяяності; формувався здебільшого "згори", під контролем двох супердержав; мав протекціоністський характер; спрямовувався, як правило, на вирішення економічних проблем чи питань безпеки; передбачав відносини між суверенними державами. Його зміст був нерозривно пов'язаний із політикою лібералізації ринків через втручання держави. Саме тому, 3 позиції старого регіоналізму, створення Європейського Союзу є захисною реакцією Європи на атаки глобального транснаціонального капіталу.

Новий економічний регіоналізм пов'язаний з відкритістю національних економічних систем завдяки діям глобальних бізнес-акторів як суб'єктів глобального простору. Метою відкритого регіоналізму $є$ формування оптимальних економічних просторів регіонального характеру, вільне переміщення капіталів, товарів, послуг і робочої сили між учасниками інтеграційних об'єднань та їх найбільш ефективна комбінація. У цьому контексті регіональна інтеграція є складовою процесу глобалізації.

Сказане дає підстави стверджувати, що новий регіоналізм поступово перетворюеться із суттєвої флуктуації в атрактор структурування світового економічного середовища. Активізація приватного підприємництва та примноження точок локалізації прискореного економічного розвитку інтенсифікують позитивні зворотні зв'язки, що приско- 
рюють інтеграційні процеси світової економіки. Ідеться також про те, що сучасним регіональним об'єднанням легше й ефективніше вписатися в процеси глобалізації та отримати вагомі вигоди від синергійного ефекту використання інвестиційної енергії міжнародного фінансового капіталу.

Трактуючи поняття "відкритого регіоналізму" як домінуючої теоретичної моделі відносин (глобалізація - регіоналізація), сучасні західні дослідники звертають увагу на те, що відкритий регіоналізм:

- передбачає утвердження організаційних форм, основаних на принципах односторонньої лібералізації та відмови від дискримінації, що означає надання локальних преференцій як членам, так і не членам об'сднання;

- $\quad \epsilon$ проектом, учасники якого допускають розширення складу об'єднання у разі дотримання претендентами відповідних правил і критеріїв угоди;

- $\quad$ с реакцією урядів на потреби корпорацій покращити свої позиції на глобальних ринках;

- $\varepsilon$ синонімом лібералізму, орієнтованого на максимально можливе використання переваг глобального ринку;

- може трактуватися як мезоглобалізація $[10$, с. 75$]$.

Зауважимо, що вектор зазначених мезопроцесів спрямований на пошук оптимальних форм об'єднання локальних співтовариств та звернення до солідарності як природного способу виживання в глобальних процесах. Мезорівень упорядковує, організовує та гармонізує енергетику різноспрямованих загальнопланетарних та місцевих етнокультурних процесів, сприяє забезпеченню діалектичної єдності універсальних та національних цінностей, зміцнює основи гомеостазису системи. Йдеться про те, що всупереч поширеним уявленням у ході глобалізації перепони між різними сегментами світу не руйнуються, а перетворюються в механізми 3 керованими потоками обмінів.

Таким чином, за сучасних умов світова економічна система має розглядатися як складна трирівнева комбінація національних, регіональних та глобальної економічних систем і відповідних їм ринків. При цьому:

- державні устрої, національні економіки та чіткі кордони юрисдикцій державнацій не збігаються з розмитими лініями глобальних економічних систем;

- нації економічно взаємозалежні, оскільки в межах своїх транснаціональних та регіональних структур вони володіють спільними елементами економічних систем;

- високий рівень взаємозалежності й інтегрованості економічних систем у глобальній економіці супроводжуеться виникненням системного й синергетичного ефектів;

- всі країни, яким належать частини спільного економічного простору, зацікавлені в ефективності глобальної економічної системи [11, с. 11].

Дещо інакше визначас цю проблему А. Мокій, на думку якого сучасне світове господарство слід розглядати в контексті нової тривимірної структури розвитку світового господарства: глобалізації, локалізації та маргіналізації як триєдиної сукупності "глобальноі" економіки світових лідерів, макрорегіональних “локальних" економічних угрупувань i “маргінальних" економік'країн, що не залучені до зазначених процесів $[12$, с. 160$]$.

Висновки. Дослідження показало, що глобалізація має суперечливий вплив на трансформаційний потенціал національних економічних систем, які функціонують у несприятливих умовах зростання нестійкості світогоспгодарської системи та прискореного входження в структури уже сформованих економічних зв' язків. Пошуковоекспериментальний характер економічних та інституційних трансформацій цих країн доповнюється розщепленням національних господарських комплексів та руйнацісю сформованих виробничих зв'язків; випереджальною зовнішньоекономічною лібералізацією, яка створює переважно зовнішній, а не внутрішній тиск на національних товаровиробників, ускладнюючи можливості їх пристосування до конкурентного середовища; прискореною лібералізацією валютно-фінансової сфери, що формує передумови для перекачування капіталу з проблемного реального сектору в більш

SCIENTIFIC BULLETIN OF THE NATIONAL ACADEMY
OF STATISTICS, ACCOUNTING AND AUDIT, 2017, No 4


КОНЦЕПТУАЛЬНІ ПЦХОДИ ДО ДОСЛДЖЕННЯ РОЗВИТКУ ГОСПОДАРСЬКИХ СИСТЕМ В УМОВАХ ГЛОБАЛІЗАЦІЇ ТА РЕГГОНАЛІЗАЦӤ

гнучкий сектор валютних операцій та операцій $з$ цінними паперами; скороченням можливостей національних урядів щодо регулювання торгівлі, конкурентних відносин, реалізації податкової політики, досягнення цілей суспільного добробуту; зростанням домінування ТНК та відпливом продуктивних ресурсів, що позбавляє національні економіки важливих джерел саморозвитку і призводить до структурного спрощення їх народногосподарських комплексів; різкою майновою диференціацією суспільства, збільшенням частки населення 3 низькими доходами.

\section{Список використаних джерел}

1. Усатенко I. А. Розвиток глобалізаційних процесів у поглядах I. Валлерстайна // Наукові праці. Історія. 2012. Вип. 168. Т. 180. С. 95-99.

2. Шталь Т. В., Доброскок Ю. Б., Тищенко О. О. та ін. Глобальна економіка: навч. посіб. Харків: Вид-во “Форт”, 2016. 358 с.

3. Пасічна О. Ю. Теоретичні основи формування зовнішньоекономічної стратегії держави в умовах інтернаціоналізації світових економічних процесів // Вісник Чернівецького торговельно-економічного інституту. Економічні науки. 2010. Вип. 3. C. $35-40$.

4. Кастельс М., Химанен П. Информационное общество и государство благосостояния: Финская модель. М.: Логос, 2002. 219 с.

5. Стратегії економічного розвитку в умовах глобалізації / За ред. Д. Г. Лук'яненка. K.: KHEУ, $2001.538 \mathrm{c}$.

6. Білорус О. Г., Лук'яненко Д. Г. та ін. Глобалізація і безпека розвитку. К.: КНЕУ, $2001.733 \mathrm{c}$.

7. Лукашевич В. М. Глобалистика : учеб. пособ. Л.: Новий світ, 2000, 2004. 392 с.

8. Мочерний С.В., Ларіна Я. С., Фомішин С. В. Світове господарство в умовах глобалізації: моногр. К.: Ніка-центр, 2006. 200 с.

9. Цивилизационная структура современного мира: моногр. В 3-х т. Т. 1. Глобальные трансформации современности / Под ред. Ю. Н. Пахомова.'К.: Наук. думка, 2006. $687 \mathrm{c}$.

10. Менеджмент європейської економічної інтеграції: підруч. / Ред. С. М. Писаренко. К.: Знання, 2012. $373 \mathrm{c.}$

11. Tapinos G., Delaunay D. Can one really talk of the globalisation of migration flows? // Globalisation, Migration and Development. Paris: OECD, 2000. 200 p.

12. Мокій А. І., Яхно Т. П., Бабець І. Г. Міжнародні організації: навч. посіб. К.: Центр учбової літератури, 2011.280 с.

\section{д. И. КОЛОМИЙчУК, аспирант, \\ Харьковский начиональный университет имени В. Н. Каразина}

\section{Концептуальные подходы к развитию хозяйственных систем в условиях глобализации и регионализации}

В статье обосновано взаииодействие начионального и глобального в экономических преобразованиях в открытых хозяйственных системах. Определены концептуальные подходы к развитию хозяйственных систем в условиях глобализачии и регионализачии.

Ключевые слова: экономика, глобализачия, интерначионализаџия, регионализачия, регионализм. 


\section{I. KOLOMYYCHUK, \\ Post-Graduate Student, \\ V. N. Karazin Kharkiv National University}

\section{Conceptual Approaches to the Development of Economic Systems in the Context of Globalization and Regionalization}

Interactions of the national and the global in economic transformations occurring in open economic systems are substantiated. Conceptual approaches to the development of economic systems in the globalization and regionalization context are summed up.

It is shown that globalization is a logical consequence of mutual influences and interactions of multiple local transformations in socio-economic systems of various levels, which planetary self-organization generates the new quality of the global economic development.

It is concluded that globalization has controversial impact on the transformation capacities of national economic systems that have to operate in the unfavorable condition of the growing instability of the global economic system and rapid integration in the structures with already established economic relations. The heuristic and experimental nature of economic and institutional transformations in these countries is added by splits of national economic systems and disruptions of established production links; the outstripping liberalization of foreign economic relations, creating rather external than internal pressures on national manufacturers and making them less capable to adapt to the competitive environment; the accelerated liberalization of monetary and financial systems, opening up ways to reallocation of capital from the sluggish real sector to the more flexible sector of transactions with currencies and securities; the shrinking regulatory authorities of national governments with respect of trade, competition, tax policies or social welfare; the growing domination of TNC and outflow of productive resources from national economies, important for their self-development, thus making their economic systems structurally primitive; the sharp property differentiation within societies and the increasing shares of population with low incomes.

Keywords: economy, globalization, internationalization, regionalization, regionalism.

Посилання на статтю:

Коломийчук Д. І. Концептуальні підходи до дослідження розвитку господарських систем в умовах глобалізації та регіоналізації // Науковий вісник Національної академії статистики, обліку та аудиту: зб. наук. пр.. 2017. №4. С. 79-86. 